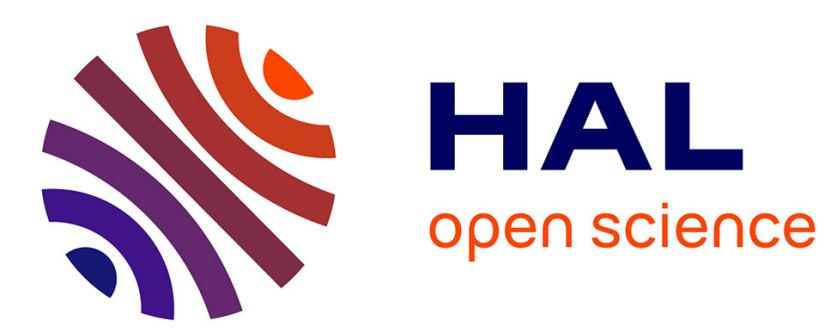

\title{
Preparation of unsymmetrically 2A,3B,6C(F)-trihydroxy-per-O-methylated $\alpha$-cyclodextrin and NMR analysis
}

Sulong Xiao, Demin Zhou, Lihe Zhang, Pierre Sinaÿ, Yongmin Zhang

\section{- To cite this version:}

Sulong Xiao, Demin Zhou, Lihe Zhang, Pierre Sinä̈, Yongmin Zhang. Preparation of unsymmetrically 2A,3B,6C(F)-trihydroxy-per-O-methylated $\alpha$-cyclodextrin and NMR analysis. Tetrahedron Letters, 2020, 61 (33), pp.152224. 10.1016/j.tetlet.2020.152224 . hal-02924680

\section{HAL Id: hal-02924680 \\ https: / hal.sorbonne-universite.fr/hal-02924680}

Submitted on 28 Aug 2020

HAL is a multi-disciplinary open access archive for the deposit and dissemination of scientific research documents, whether they are published or not. The documents may come from teaching and research institutions in France or abroad, or from public or private research centers.
L'archive ouverte pluridisciplinaire HAL, est destinée au dépôt et à la diffusion de documents scientifiques de niveau recherche, publiés ou non, émanant des établissements d'enseignement et de recherche français ou étrangers, des laboratoires publics ou privés. 


\section{Preparation of unsymmetrically $2^{\mathrm{A}}, 3^{\mathrm{B}}, 6^{\mathrm{C}(\mathrm{F})}$-trihydroxy-per- $O$-methylated $\alpha$ - cyclodextrin and NMR analysis}

Sulong Xiao ${ }^{\text {a,b, }}$, Demin Zhou ${ }^{\text {a }}$, Lihe Zhang ${ }^{\text {a }}$, Pierre Sinaÿ ${ }^{b}$, Yongmin Zhang ${ }^{\text {b,c,* }}$

a. State Key Laboratory of Natural and Biomimetic Drugs, School of Pharmaceutical Sciences, Peking University, Beijing 100191, China;

b. Institut Parisien de Chimie Moléculaire, CNRS UMR 8232, Sorbonne Université, 4 place Jussieu, 75005 Paris, France

c. Key Laboratory of Tropical Medicinal Resource Chemistry of Ministry of Education, College of Chemistry \& Chemical Engineering, Hainan Normal University, Haikou 571158, China

Address correspondence to:

Professor Yongmin Zhang

Institut Parisien de Chimie Moléculaire, CNRS UMR 8232,

Sorbonne Université,

4 place Jussieu, 75005 Paris, France

Tel.: +33 144276153 ;

Fax: +33144275504

E-mail: yongmin.zhang@upmc.fr

Associate Professor Sulong Xiao

State Key Laboratory of Natural and Biomimetic Drugs,

Peking University

38 Xueyuan Road, Beijing, China 100191

Tel/Fax: 86-10-8280-5063

Email: slxiao@bjmu.edu.cn 


\begin{abstract}
An straightforward approach wherein an excess of diisobutylaluminum hydride (DIBAL-H, 25.0 equiv), used as a molecular scalpel, is able to strip off three methyl groups from both primary and second faces of pemethylated $\alpha$-cyclodextrin 1 to provide an unsymmetric $2^{\mathrm{A}}, 3^{\mathrm{B}}, 6^{\mathrm{C}(\mathrm{F})}$-trihydroxy-per- $O$-methylated $\alpha$-CD 6 in one step in $35 \%$ yield is first described.
\end{abstract}

Keywords:

$\alpha$-Cyclodextrin; DIBAL-H; Tri-de- $O$-methylation; Regioselectivity. 
Cyclodextrins (CDs) are a family of well-known cyclic oligosaccharides consisting of a macrocycle ring of D-gulcose subunits jointed by $\alpha$-1,4-linked glycosidic bonds. A general characteristic of CDs is their ability to form inclusion complexes with both hydrophilic and hydrophobic guest molecules to increase their solubility, dissolution rate, stability, etc. ${ }^{1}$ Recently, per- $O$-methylated $\mathrm{CDs}$ and their derivatives have attracted considerable attention due to their solubility in water $(>$ $500 \mathrm{mg} / \mathrm{mL}$ ) as well as in organic solvents. ${ }^{2-4}$ More importantly, inclusion complexes of methylated CDs are usually more stable than the corresponding complexes of unmodified CDs. ${ }^{5-7}$ There has been a growing interest in a selective chemical modification of per- $O$-methylated $\mathrm{CDs}$ with various functional groups. ${ }^{8-14}$ However, up till now, highly selective modification of per- $O$-methylated CDs to obtain trifunctionalized per- $O$-methylated $\mathrm{CDs}$ both at primary and secondary faces remains a significant challenge for synthetic chemists.

In 2000, Sinaÿ et al ${ }^{15}$ discovered that diisobutylaluminium hydride (DIBAL-H) is a reagent of choice for the achievement of a remarkable mono-de- $O$-benzylation at the $6^{\mathrm{A}}$-position or bis-de- $O$-benzylation at the $6^{\mathrm{A}}$ - and $6^{\mathrm{D}}$-positions of perbenzylated $\alpha$ - and $\beta$-CD. These results contrast with DIBAL-H promoted a selective mono-de$O$-methylation at the $6^{\mathrm{A}}$-position or bis-de- $O$-methylation at the $2^{\mathrm{A}}$ - and $3^{\mathrm{B}}$-positions of per- $O$-methylated $\alpha$ - and $\beta$-CD. ${ }^{13}$ To further gain an insight into the regioselective de- $O$-methylation properties of DIBAL-H towards per- $O$-methylated $\alpha$ - and $\beta$-CD, we have extensively studied the selective de- $O$-methylation of per- $O$-methylated $\alpha$ and $\beta$-CD by DIBAL-H, ${ }^{16-20}$ a general simple way to access to $6^{\mathrm{A}}$-hydroxyl-per- $O$ methylated $\alpha$-CD 2, $2^{\mathrm{A}}, 3^{\mathrm{B}}$-dihydroxyl-per- $O$-methylated $\alpha$-CD $\quad 3,2^{\mathrm{A}}, 3^{\mathrm{B}}, 2^{\mathrm{C}}, 3^{\mathrm{D}}-$ tetrahydroxy-per- $O$-methylated $\alpha-\mathrm{CD} \quad 4$ and $2^{\mathrm{A}}, 3^{\mathrm{B}}, 2^{\mathrm{D}}, 3^{\mathrm{E}}$-tetrahydroxy-per- $O$ methylated $\alpha$-CD 5 from per- $O$-methylated $\alpha$-CD 1 was developed, respectively (Scheme 1), using DIBAL-H as a chemical "scalpel". 13, 19 


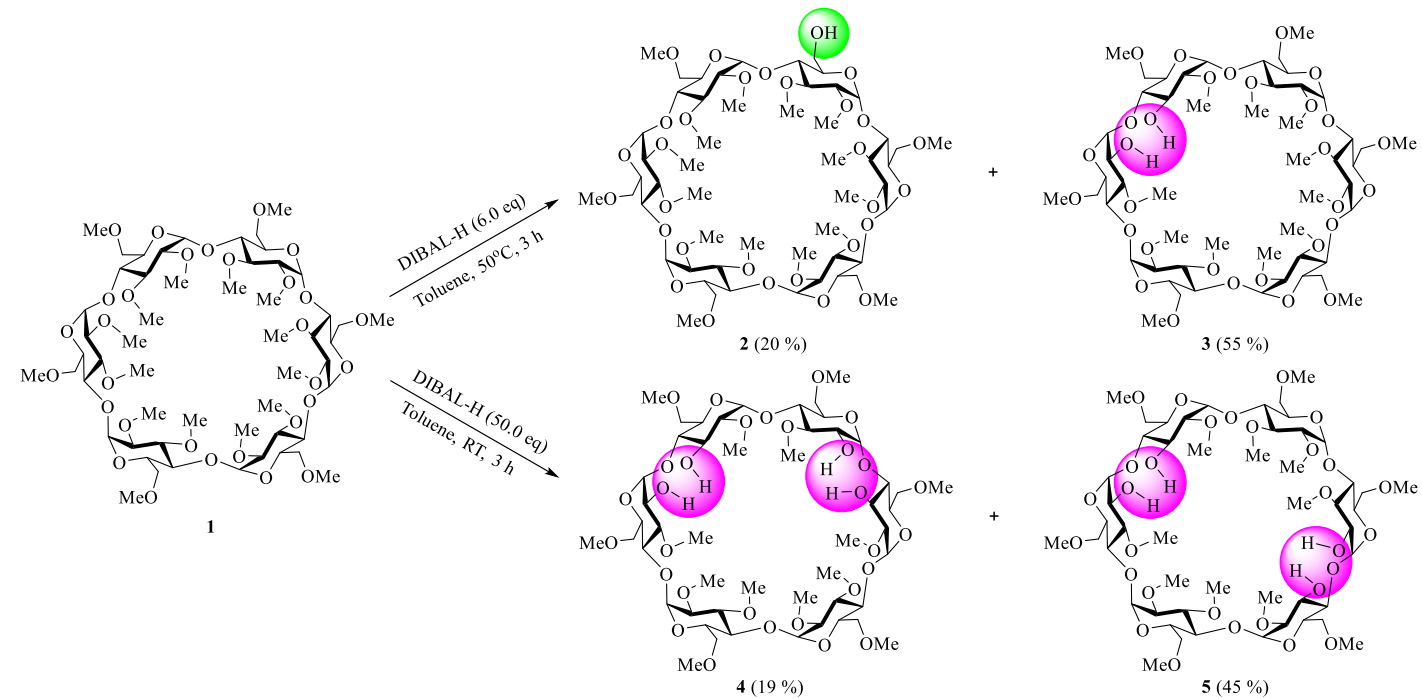

Scheme 1. Selective de- $O$-methylation of per- $O$-methylated $\alpha$-CD by DIBAL-H. ${ }^{13,19}$

In our previous study, ${ }^{16}$ a mixture of two tri-de- $O$-methylation derivatives of per- $O$-methylated $\beta$-CD promoted by DIBAL-H (50 equiv) was first observed in $17 \%$ yield and identified by FAB-MS, but was not analysed further at that stage. As a continuity to this work, we would now like to report the tri-de- $O$-methylation on both primary and secondary rims of per- $O$-methylated $\alpha$ - CD 1 to access to $2^{\mathrm{A}}, 3^{\mathrm{B}}, 6^{\mathrm{C}(\mathrm{F})}$ trihydroxy-per- $O$-methylated $\alpha$-CD 6 as one isomer by this methodology.

Based on our previous studies on the de- $O$-alkylation of per- $O$-alkylated $\mathrm{CDs},{ }^{13}$, ${ }^{15-17,19}$ we found that the reaction conditions, including the amount of DIBAL-H, the reaction temperature and the reaction time, have important effects on the selectivity of de-O-alkylation reaction. In addition, an amount of 6.0 40.0 equiv of DIBAL-H will helpful to the selectivity of tri-de- $O$-methyl reaction. After careful modification of the reaction conditions, we found that when per- $O$-methylated $\alpha$-CD 1 was treated with 25.0 equivalent of DIBAL-H in toluene $(1.0 \mathrm{M})$ at room temperature for $4 \mathrm{~h}$, $2^{\mathrm{A}}, 3^{\mathrm{B}}, 6^{\mathrm{C}(\mathrm{F})}$-trihydroxy-per- $O$-methylated $\alpha$-CD 6 was separated out in $35 \%$ yield as a major product by a regular silica-gel column chromatography (Scheme 2), along with little amount of known mixtures $4 / 5(\sim 20 \%)$, and an unsymmetric hexa-de- $O$ methylation derivative $(\sim 4 \%)$ as identified by ESI-HRMS. Based on the NMR analysis of the mono-hydroxy $\mathbf{2}$ and di-hydroxy $\mathbf{3}$ (Supporting Information, S3-S7), ${ }^{13}$, 18 the structural determination of the tri-hydroxy 6 was achieved easily through the ESI-HRMS, 1D and 2D NMR spectra. The ESI-HR mass spectrum for $\mathbf{6}$ showed an 
$[\mathrm{M}+\mathrm{Na}]^{+}$ion at $\mathrm{m} / \mathrm{z} 1205.5422 \mathrm{Da}\left(\mathrm{Calcd}\right.$ for $\left.\mathrm{C}_{51} \mathrm{H}_{90} \mathrm{NaO}_{30}, 1205.5409\right)$, indicating that it is a tri-de- $O$-methyl derivative of $\mathbf{1}$. Due to random substitution of the methyl group in the narrom and wide rims of the molecule, the ${ }^{1} \mathrm{H}$ NMR spectrum of 6 is much complicated, except the lower-field and high field regions relatively well resolved. The signal at $\delta=5.10-5.00 \mathrm{ppm}$ and $3.21-3.15 \mathrm{ppm}$, referring to $6 \mathrm{H}$ and $5 \mathrm{H}$, respectively, were assigned to $6 \times \mathrm{H}_{1}$ and $5 \times \mathrm{H}_{2}$, and six carbons appearing at 99.65 (2C), 99.89, 99.93, 100.38 and 102.30 was assigned to $\mathrm{C}_{1}$ (Figure 1). With the aid of ${ }^{1} \mathrm{H}-{ }^{13} \mathrm{C}$ HSQC spectrum (Figure S1) and the Jmod spectra of compounds 2, 3 and $\mathbf{6}$ (Figure $\mathrm{S} 2$ ), some key signals such as $\mathrm{H}_{2}{ }^{\mathrm{A}}, \mathrm{H}_{3}{ }^{\mathrm{B}}$ and $\mathrm{H}_{6}{ }^{\mathrm{C}(\mathrm{F})}$ are unambiguously isolated. The triplet at $\delta=4.12 \mathrm{ppm}(J=9.4 \mathrm{~Hz})$ and $3.59 \mathrm{ppm}$ (overlap with others), each referring to $1 \mathrm{H}$, was assigned to $\mathrm{H}_{3}{ }^{\mathrm{B}}$ and $\mathrm{H}_{2}{ }^{\mathrm{A}}$, respectively, and two carbons appearing at $71.75 \mathrm{ppm}$ and $73.47 \mathrm{ppm}$ were assigned to $\mathrm{C}_{3}{ }^{\mathrm{B}}$ and $\mathrm{C}_{2}{ }^{\mathrm{A}}$, respectively. The multiple signals at $\delta=4.01-3.95 \mathrm{ppm}$, referring to $2 \mathrm{H}$, was assigned to $\left.2 \times \mathrm{H}_{6}{ }^{\mathrm{C}}{ }^{\mathrm{F}}\right)$, and one carbon appearing at $62.37 \mathrm{ppm}$ was assigned to $\mathrm{C}_{6} \mathrm{C}(\mathrm{F})$. The structure of compound 6 was further confirmed using tandem mass spectrometry (MS/MS) techniques (Figures S3-S5). These data clearly shows the cleavage of mono-hydroxy monosaccharide (m/z 191.10), di-hydroxy disaccharide (m/z 381.20) and tri-hydroxy trisaccharide (m/z 571.30) fragments from compound 6, which indicate the C6-OH should be located at $\mathrm{C}$ or $\mathrm{F}$ glucose subunit. To our knowledge, the further determination of the position of C6-OH, which marked by an asterisk (Scheme 2), would be still difficult since there is no accumulation of spectral data for such systems.

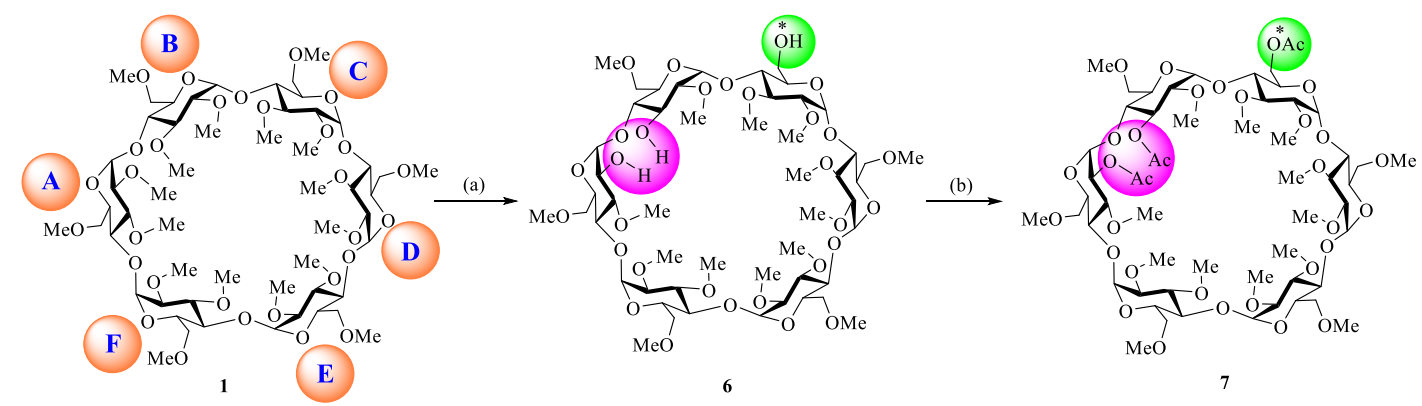

Scheme 2. Reagents and conditions: (a) DIBAL-H (25.0 equiv), RT, 4 h, 35\%; (b) $\mathrm{Ac}_{2} \mathrm{O}$, pyridine, DMAP, RT, $18 \mathrm{~h}, 90 \%$. Asterisks indicated that the position of hydroxyl or oxyacetyl group locate at $\mathrm{C}$ or $\mathrm{F}$ glucose subunit. 


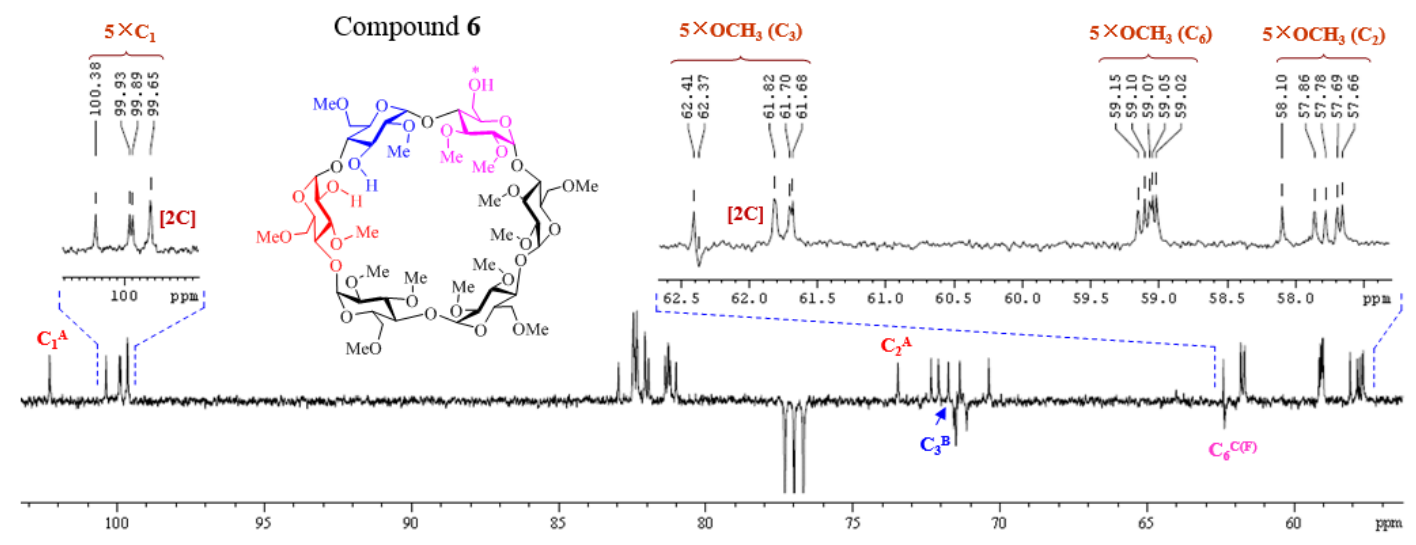

Figure 1. $400 \mathrm{MHz}$ Jmod spectrum $\left(\mathrm{CDCl}_{3}, 298 \mathrm{~K}\right)$ of the tri-hydroxy 6. Asterisk indicated that the position of hydroxyl locate at $\mathrm{C}$ or $\mathrm{F}$ glucose subunit.

The structure of tri-hydroxy $\mathbf{6}$ was further confirmed by its acetylated derivative 7. By comparing their spectral data of 7 with those of $6^{\mathrm{A}}-O$-acetyl-per- $O$-methylated $\alpha$-CD 8 and $2^{\mathrm{A}}, 3^{\mathrm{B}}$-di- $O$-acetyl-per- $O$-methylated $\alpha$-CD 9 (Supporting Information, S13-S14), which were prepared according to the procedure described by du Roizel ${ }^{13}$ with minor modifications,${ }^{20}$ several deshielded signals were assigned conveniently. The low-field doublet of doublets at $4.69 \mathrm{ppm}\left(J_{2,3}=10.4 \mathrm{~Hz}, J_{1,2}=2.8 \mathrm{~Hz}\right)$ and at $5.45 \mathrm{ppm}\left(J_{2,3}=10.4 \mathrm{~Hz}, J_{3,4}=9.2 \mathrm{~Hz}\right)$, each referring to $1 \mathrm{H}$, which, according to their ${ }^{1} \mathrm{H}-{ }^{1} \mathrm{H}$ coupling constants and their ${ }^{1} \mathrm{H}-{ }^{13} \mathrm{C}$ correlation spectra, could be assigned to $\mathrm{H}_{2}{ }^{\mathrm{A}}$ and $\mathrm{H}_{3}{ }^{\mathrm{B}}$, respectively. From the ${ }^{1} \mathrm{H}^{13} \mathrm{C}$ correlation spectrum, two carbons appearing at 74.35 and $71.67 \mathrm{ppm}$, could be assigned to $\mathrm{C}_{2}{ }^{\mathrm{A}}$ and $\mathrm{C}_{3}{ }^{\mathrm{B}}$, respectively (Figure S6). The broad doublet at $\delta=4.58 \mathrm{ppm}\left(J_{6 \mathrm{a}, 6 \mathrm{~b}}=12.4 \mathrm{~Hz}\right)$ and doublet of doublets at $4.36 \mathrm{ppm}\left(J_{6 \mathrm{a}, 6 \mathrm{~b}}=12.4 \mathrm{~Hz}, J_{5,6 \mathrm{a}}=3.2 \mathrm{~Hz}\right)$, each referring to $1 \mathrm{H}$, was assigned to $2 \times \mathrm{H}_{6}{ }^{\mathrm{C}(\mathrm{F})}$, and one carbon appearing at $63.53 \mathrm{ppm}$ was assigned to $\mathrm{C}_{6}{ }^{\mathrm{C}(\mathrm{F})}$, due to the acetylation of the hydroxyl group. Clearly, the high-field signal at 2.21, 2.19 and $2.08 \mathrm{ppm}$, each referring to $3 \mathrm{H}$, was assigned to three acetyl groups, and six carbons appearing at 170.54, 170.42, 170.37 and 21.68, 21.44, 20.89 ppm could be assigned to three carbonyl and methyl groups of acetates, respectively. The NMR spectra of 7 further confirms the presence of a free $\mathrm{C} 2-\mathrm{OH}$ and a freee $\mathrm{C} 3-\mathrm{OH}$ which located at two adjacent sugars and a free C6-OH in tri-hydroxy 6.

Combined with our previous studies, ${ }^{13}, 19$ the DIBAL-H promoted regioselective 
de-O-methylation of 1 may include the following steps (Scheme 3): the first step would be a mono-de- $O$-methylation at $\mathrm{C}_{6}$ of one sugar and bis-de- $O$-methylation at $\mathrm{C}_{2}$ and $\mathrm{C}_{3}$ of two adjacent sugar units to afford the mono-hydroxy 2 and the dihydroxy 3 , respectively. ${ }^{13}$ The second step would be a bis-de- $O$-methylation at $\mathrm{C}_{2}$ and $\mathrm{C}_{3}$ of two adjacent sugar units of the mono-hydroxy 2 or a mono-de- $O$ methylation at $\mathrm{C}_{6}$ of the di-hydroxy 3 to afford the tri-hydroxy 6 ; or a duplication of bis-de- $O$-methylation at $\mathrm{C}_{2}$ and $\mathrm{C}_{3}$ at other two adjacent sugar units of di-hydroxy 3 to afford the tetra-hydroxys $\mathbf{4}$ and $\mathbf{5}$. Theoritically, further careful modification of the reaction conditions by using a higher DIBAL-H concentration and/or a prolonged period of reaction time should allow to hexa-de- $O$-methylation of $\mathbf{1}$ to access to $2^{\mathrm{A}}, 3^{\mathrm{B}}, 2^{\mathrm{C}}, 3^{\mathrm{D}}, 2^{\mathrm{E}}, 3^{\mathrm{F}}$-hexahydroxy-per- $O$-methylated $\alpha$-CD 10 . However, in spite of our efforts, we were unable to get it.

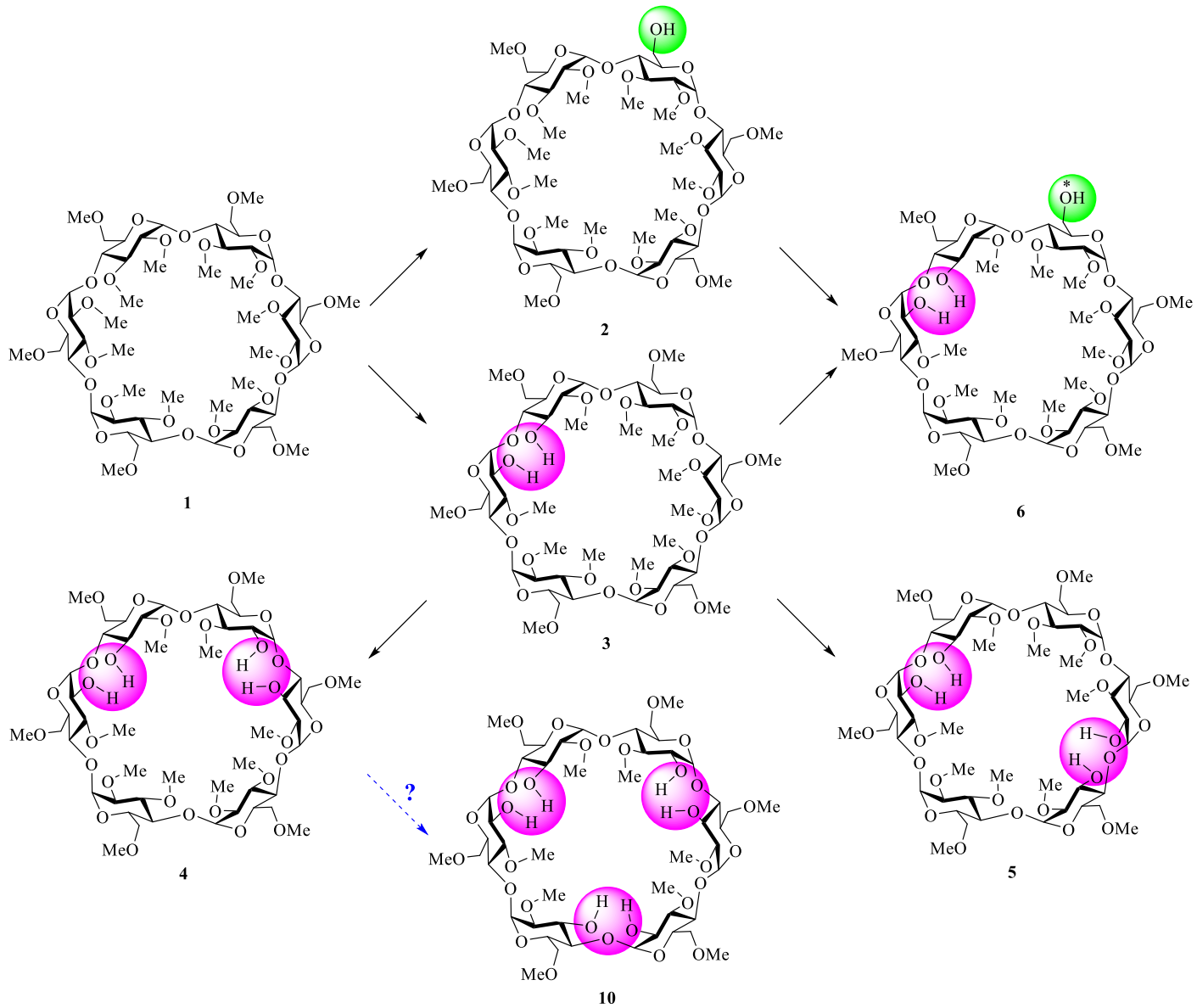

Scheme 3. Proposed pathway for the formation of $2^{\mathrm{A}}, 3^{\mathrm{B}}, 6^{\mathrm{C}(\mathrm{F})}$-tri-hydroxy 6 from per$O$-methylated $\alpha$-CD 1. Asterisk indicated that the position of hydroxyl locate at $\mathrm{C}$ or 
F glucose subunit.

As already observed in our previous studies, ${ }^{13,16,17,19}$ no simultaneous de-Omethylation on both primary and secondary faces at the same molecule of per- $O$ methylated $\alpha$ - and $\beta$-CD has been isolated and characeterized. It is generally believed that once mono-de- $O$-methylation on the primay face or bis-de- $O$-methylation on the secondary face happened, no further de- $O$-methylation on the other face takes place. ${ }^{13}$ It is the first time for us to isolate tri-de- $O$-methylation on both faces of per- $O$ methylated $\alpha-C D 1$ as a signle isomer in only one chemical operation using DIBAL$\mathrm{H}$ as a chemical "scalpel". Statistical calculations indicate that for tri-de- $O$ methylation of per- $O$-methylated $\alpha$-CD 1109 regioisomers are possible, of which, we obtain only one single isomer as a major product, indicating the remarkable regioselectivity of DIBAL-H promoted tri-de- $O$-methylation of per- $O$-methylated $\alpha$ -

CD 1. As the nucleophilicity/reactivity of the three hydroxys are different, which provide a potential method for unsymmetrical introduction of three functional groups into per- $O$-methylated $\alpha$-CD derivatives directly.

\section{Experimantal section}

\section{General procedures}

Optical rotations were measured at $20 \pm 2{ }^{\circ} \mathrm{C}$ with a Perkin Elmer Model 343 digital polarimeter, using a $10 \mathrm{~cm}, 1 \mathrm{~mL}$ cell. High Resolution Mass Spectrometry (HRMS) were obtained with an APEX IV FT-MS (7.0 T) spectrometer (Bruker). The collision-activated dissociation (CID) tandem mass spectrometry (MS/MS) were obtained with Waters Synapt G2-Si spectrometer. NMR spectra were recorded on a Bruker DRX 400 spectrometer at ambient temperature. ${ }^{1} \mathrm{H}$ NMR chemical shifts are referenced to internal standard tetramethylsilane (TMS) $\left(\delta_{\mathrm{H}}=0.00 \mathrm{ppm}\right) .{ }^{13} \mathrm{C} \mathrm{NMR}$ chemical shifts are referenced to the solvent signal $\left(\delta_{\mathrm{C}}=77.00\right.$ for the central line of $\mathrm{CDCl}_{3}$ ). Reactions were monitored by thin-layer chromatography (TLC) on a precoated silica gel $60 \mathrm{~F}_{254}$ plate (layer thickness $0.2 \mathrm{~mm}$; E. Merck, Darmstadt, Germany) and detected by charring with a $10 \%$ solution of sulphuric acid in ethanol. Flash column chromatography was performed on silica gel 60 (200-300 mesh, Qingdao Haiyang Chemical Co. Ltd). 


\section{$2^{\mathrm{A}}, 3^{\mathrm{B}}, 6^{\mathrm{C}(\mathrm{F})}$-trihydroxyl per- $O$-methylated $\alpha$-CD (6)}

To a solution of dried hexakis (2,3,6-tri- $O$-methyl)- $\alpha$-CD 1 (271 mg, $0.22 \mathrm{mmol})$ was added $5.5 \mathrm{~mL}$ (5.5 mmol, 25.0 equiv) of DIBAL-H (1.0 $\mathrm{M}$ in toluene) at room temperature under nitrogen. The mixture was stirred for $4 \mathrm{~h}$. Aqueous $\mathrm{HCl}(1.0 \mathrm{M})$ was carefully added dropwise to quench the reaction and the mixture was stirred vigorously at room temperature for $30 \mathrm{~min}$. The toluene phase was separated and the water phase was extracted by ethyl acetate $(3 \times 20 \mathrm{~mL})$. The combined organic phase was washed with brine, dried with $\mathrm{MgSO}_{4}$, filtrated and the solvent was removed in vacuo. The residue was subjected to flash chromatography (eluent: $\mathrm{CH}_{2} \mathrm{Cl}_{2} / \mathrm{CH}_{3} \mathrm{OH}$ $=50: 1-30: 1)$ to give tri-hydroxy 6 as a white foam in $35 \%$ yield. $\mathrm{R}_{\mathrm{f}}=0.16$ $\left(\mathrm{CH}_{2} \mathrm{Cl}_{2} / \mathrm{CH}_{3} \mathrm{OH}=10: 1\right) ;[\alpha]_{\mathrm{D}}+146\left(\mathrm{c}=1.0\right.$ in $\left.\mathrm{CHCl}_{3}\right) ;{ }^{1} \mathrm{H}$ NMR $\left(400 \mathrm{MHz}, \mathrm{CDCl}_{3}\right)$ : $\delta 3.15-3.21\left(\mathrm{~m}, 5 \mathrm{H}, 5 \times \mathrm{H}_{2}\right), 3.40\left(\mathrm{br} \mathrm{s}, 9 \mathrm{H}, 3 \times \mathrm{OCH}_{3}\left(\mathrm{C}_{6}\right)\right), 3.41\left(\mathrm{~s}, 3 \mathrm{H}, \mathrm{OCH}_{3}\left(\mathrm{C}_{6}\right)\right)$, $3.42\left(\mathrm{~s}, 3 \mathrm{H}, \mathrm{OCH}_{3}\left(\mathrm{C}_{6}\right)\right), 3.47\left(\mathrm{~s}, 3 \mathrm{H}, \mathrm{OCH}_{3}\left(\mathrm{C}_{2}\right)\right), 3.49\left(\mathrm{~s}, 3 \mathrm{H}, \mathrm{OCH}_{3}\left(\mathrm{C}_{2}\right)\right), 3.50$ (s, $\left.6 \mathrm{H}, 2 \times \mathrm{OCH}_{3}\left(\mathrm{C}_{2}\right)\right), 3.51\left(\mathrm{~s}, 3 \mathrm{H}, \mathrm{OCH}_{3}\left(\mathrm{C}_{2}\right)\right), 3.60\left(\mathrm{~m}, 1 \mathrm{H}, \mathrm{H}_{2}{ }^{\mathrm{A}}\right), 3.61\left(\mathrm{~s}, 3 \mathrm{H}, \mathrm{OCH}_{3}\right.$ $\left.\left(\mathrm{C}_{3}\right)\right), 3.63\left(\mathrm{~s}, 6 \mathrm{H}, 2 \times \mathrm{OCH}_{3}\left(\mathrm{C}_{3}\right)\right), 3.64\left(\mathrm{~s}, 3 \mathrm{H}, \mathrm{OCH}_{3}\left(\mathrm{C}_{3}\right)\right), 3.68\left(\mathrm{~m}, 1 \mathrm{H}, \mathrm{H}_{4}{ }^{\mathrm{B}}\right), 3.74$ (s, 3H, $\left.\mathrm{OCH}_{3}\left(\mathrm{C}_{3}\right)\right), 3.95-4.01\left(\mathrm{~m}, 2 \mathrm{H}, 2 \times \mathrm{H}_{6 \mathrm{a}}{ }^{\mathrm{C}(\mathrm{F})}\right), 3.47-4.01\left(\mathrm{~m}, 27 \mathrm{H}, 5 \times \mathrm{H}_{3}, 5 \times \mathrm{H}_{4}\right.$, $\left.6 \times \mathrm{H}_{5}, 5 \times \mathrm{H}_{6 \mathrm{a}}, 6 \times \mathrm{H}_{6 \mathrm{~b}}\right), 4.12\left(\mathrm{t}, 1 \mathrm{H}, J_{2,3}=J_{3,4}=9.4 \mathrm{~Hz}, \mathrm{H}_{3}{ }^{\mathrm{B}}\right), 5.01\left(\mathrm{~d}, 1 \mathrm{H}, J_{1,2}=2.8 \mathrm{~Hz}\right.$, $\left.\mathrm{H}_{1}{ }^{\mathrm{A}}\right), 5.03\left(\mathrm{~d}, 1 \mathrm{H}, J_{1,2}=3.2 \mathrm{~Hz}, \mathrm{H}_{1}\right), 5.04-5.05\left(\mathrm{~m}, 2 \mathrm{H}, 2 \times \mathrm{H}_{1}\right), 5.09-5.10(\mathrm{~m}, 2 \mathrm{H}$, $\left.2 \times \mathrm{H}_{1}\right) ;{ }^{13} \mathrm{C} \mathrm{NMR}\left(100 \mathrm{MHz}, \mathrm{CDCl}_{3}\right): \delta 57.66,57.69,57.78,57.86,58.10$ (5C, $\left.5 \times \mathrm{OCH}_{3}\left(\mathrm{C}_{2}\right)\right), 59.02,59.05,59.07,59.11,59.15\left(5 \mathrm{C}, 5 \times \mathrm{OCH}_{3}\left(\mathrm{C}_{6}\right)\right), 61.68,61.71$, 61.82, $\left.62.41\left(5 \mathrm{C}, 5 \times \mathrm{OCH}_{3}\left(\mathrm{C}_{3}\right)\right), 62.37\left(\mathrm{C}_{6}{ }^{\mathrm{C}} \mathrm{F}\right)\right), 70.38,71.37,72.09,72.34(6 \mathrm{C}$, $\left.6 \times \mathrm{C}_{5}\right), 71.13,71.49,71.57\left(5 \mathrm{C}, 5 \times \mathrm{C}_{6}\right), 71.75\left(\mathrm{C}_{3}{ }^{\mathrm{B}}\right), 73.47\left(\mathrm{C}_{2}{ }^{\mathrm{A}}\right), 81.01,81.20,81.27$, $81.28,81.38,81.95,82.06,82.32,82.35,82.42,82.46,82.96\left(16 \mathrm{C}, 5 \times \mathrm{C}_{2}, 5 \times \mathrm{C}_{3}\right.$, $\left.6 \times \mathrm{C}_{4}\right), 99.65,99.89,99.93,100.38\left(5 \mathrm{C}, 5 \times \mathrm{C}_{1}\right), 102.30\left(\mathrm{C}_{1}{ }^{\mathrm{A}}\right) ;$ ESI-HRMS $(\mathrm{m} / \mathrm{z}) \mathrm{Calcd}$ for $\mathrm{C}_{51} \mathrm{H}_{90} \mathrm{O}_{30} \mathrm{Na}[\mathrm{M}+\mathrm{Na}]^{+}:$1205.5415. Found 1205.5422.

\section{$2^{\mathrm{A}}, 3^{\mathrm{B}}, 6^{\mathrm{C}(\mathrm{F})}$-tri- $O$-acetyl per- $O$-methylated $\alpha$-CD (7)}

To a solution of 6 (25 mg, $0.021 \mathrm{mmol})$ in dry pyridine $(2 \mathrm{~mL})$ was added 2.6 mg of DMAP (0.021 mmol, 1.0 equiv) and $1 \mathrm{~mL} \mathrm{Ac}_{2} \mathrm{O}$ at room temperature. The reaction mixture was stirred for $18 \mathrm{~h}$ under nitrogen. The solvent was removed in vacuo. The residue was subjected to flash chromatography (eluent: $\mathrm{CH}_{2} \mathrm{Cl}_{2} / \mathrm{CH}_{3} \mathrm{OH}$ 
$=50: 1)$ to give $35.1 \mathrm{mg}(90 \%)$ of compound 7 as a white foam. $\mathrm{R}_{\mathrm{f}}=0.37$ $\left(\mathrm{CH}_{2} \mathrm{Cl}_{2} / \mathrm{CH}_{3} \mathrm{OH}=20: 1\right) ;[\alpha]_{\mathrm{D}}+139\left(\mathrm{c}=1.0\right.$ in $\left.\mathrm{CHCl}_{3}\right) ;{ }^{1} \mathrm{H} \mathrm{NMR}\left(400 \mathrm{MHz}, \mathrm{CDCl}_{3}\right)$ : $\delta 2.08\left(\mathrm{~s}, 3 \mathrm{H}, \mathrm{CH}_{3} \mathrm{CO}\left(\mathrm{C}_{6}{ }^{\mathrm{C}(\mathrm{F})}\right)\right), 2.19,2.21\left(2 \times \mathrm{s}, 6 \mathrm{H}, 2 \times \mathrm{CH}_{3} \mathrm{CO}\left(\mathrm{C}_{2}{ }^{\mathrm{A}}, \mathrm{C}_{3}{ }^{\mathrm{B}}\right)\right), 3.13-3.19$ $\left(\mathrm{m}, 4 \mathrm{H}, 4 \times \mathrm{H}_{2}\right), 3.21\left(\mathrm{dd}, 1 \mathrm{H}, J_{1,2}=3.2 \mathrm{~Hz}, J_{2,3}=9.2 \mathrm{~Hz}, \mathrm{H}_{2}{ }^{\mathrm{B}}\right), 3.38\left(\mathrm{~s}, 3 \mathrm{H}, \mathrm{OCH}_{3}\right.$ $\left.\left(\mathrm{C}_{6}\right)\right), 3.39\left(2 \times \mathrm{s}, 9 \mathrm{H}, 3 \times \mathrm{OCH}_{3}\left(\mathrm{C}_{6}\right)\right), 3.40\left(\mathrm{~s}, 3 \mathrm{H}, \mathrm{OCH}_{3}\left(\mathrm{C}_{6}\right)\right), 3.43\left(\mathrm{~s}, 3 \mathrm{H}, \mathrm{OCH}_{3}\left(\mathrm{C}_{2}\right)\right)$, $3.46\left(\mathrm{~s}, 3 \mathrm{H}, \mathrm{OCH}_{3}\left(\mathrm{C}_{2}\right)\right), 3.47\left(\mathrm{~s}, 3 \mathrm{H}, \mathrm{OCH}_{3}\left(\mathrm{C}_{2}\right)\right), 3.51\left(2 \times \mathrm{s}, 6 \mathrm{H}, 2 \times \mathrm{OCH}_{3}\left(\mathrm{C}_{2}\right)\right), 3.56$ (s, 3H, $\left.\mathrm{OCH}_{3}\left(\mathrm{C}_{3}\right)\right), 3.57\left(\mathrm{~s}, 3 \mathrm{H}, \mathrm{OCH}_{3}\left(\mathrm{C}_{3}\right)\right), 3.62\left(\mathrm{~s}, 3 \mathrm{H}, \mathrm{OCH}_{3}\left(\mathrm{C}_{3}\right)\right), 3.63(\mathrm{~m}, 1 \mathrm{H}$, $\left.\mathrm{H}_{3}{ }^{\mathrm{A}}\right), 3.64\left(\mathrm{~s}, 3 \mathrm{H}, \mathrm{OCH}_{3}\left(\mathrm{C}_{3}\right)\right), 3.69\left(\mathrm{~s}, 3 \mathrm{H}, \mathrm{OCH}_{3}\left(\mathrm{C}_{3}\right)\right), 3.77\left(\mathrm{~m}, 1 \mathrm{H}, \mathrm{H}_{4}{ }^{\mathrm{B}}\right), 3.95(\mathrm{~m}$, $\left.1 \mathrm{H}, \mathrm{H}_{5}{ }^{\mathrm{C}(\mathrm{F})}\right), 3.43-4.07\left(\mathrm{~m}, 24 \mathrm{H}, 4 \times \mathrm{H}_{3}, 5 \times \mathrm{H}_{4}, 5 \times \mathrm{H}_{5}, 5 \times \mathrm{H}_{6 \mathrm{a}}, 5 \times \mathrm{H}_{6 \mathrm{~b}}\right), 4.36\left(\mathrm{dd}, 1 \mathrm{H}, J_{5,6 \mathrm{a}}\right.$ $\left.=3.2 \mathrm{~Hz}, J_{6 \mathrm{a}, 6 \mathrm{~b}}=12.4 \mathrm{~Hz}, \mathrm{H}_{6 \mathrm{a}}{ }^{\mathrm{C}(\mathrm{F})}\right), 4.58\left(\mathrm{br} \mathrm{d}, 1 \mathrm{H}, J_{6 \mathrm{a}, 6 \mathrm{~b}}=12.4 \mathrm{~Hz}, \mathrm{H}_{6 \mathrm{~b}}{ }^{\mathrm{C}(\mathrm{F})}\right), 4.69(\mathrm{dd}$, $\left.1 \mathrm{H}, J_{1,2}=2.8 \mathrm{~Hz}, J_{2,3}=10.4 \mathrm{~Hz}, \mathrm{H}_{2}{ }^{\mathrm{A}}\right), 4.98\left(\mathrm{~d}, 1 \mathrm{H}, J_{1,2}=2.8 \mathrm{~Hz}, \mathrm{H}_{1}{ }^{\mathrm{A}}\right), 5.03-5.06(\mathrm{~m}$, $\left.4 \mathrm{H}, 4 \times \mathrm{H}_{1}\right), 5.11\left(\mathrm{~d}, 1 \mathrm{H}, J_{1,2}=3.2 \mathrm{~Hz}, \mathrm{H}_{1}{ }^{\mathrm{B}}\right), 5.45\left(\mathrm{t}, J_{2,3}=10.4 \mathrm{~Hz}, J_{3,4}=9.2 \mathrm{~Hz}, \mathrm{H}_{3}{ }^{\mathrm{B}}\right)$; ${ }^{13} \mathrm{C}$ NMR $\left(100 \mathrm{MHz}, \mathrm{CDCl}_{3}\right): \delta 20.89\left(\underline{\mathrm{CH}}_{3} \mathrm{CO}\left(\mathrm{C}_{6}{ }^{\mathrm{C}(\mathrm{F})}\right)\right), 21.43,21.68\left(2 \mathrm{C}, 2 \times \mathrm{CH}_{3} \mathrm{CO}\right.$ $\left.\left(\mathrm{C}_{2}{ }^{\mathrm{A}}, \mathrm{C}_{3}{ }^{\mathrm{B}}\right)\right), 57.49,57.82,57.96,58.01,58.27\left(5 \mathrm{C}, 5 \times \mathrm{OCH}_{3}\left(\mathrm{C}_{2}\right)\right)$, 58.81, 58.94, 59.03, $59.07\left(5 \mathrm{C}, 5 \times \mathrm{OCH}_{3}\left(\mathrm{C}_{6}\right)\right), 61.41,61.54,61.74,61.83,62.00\left(5 \mathrm{C}, 5 \times \mathrm{OCH}_{3}\left(\mathrm{C}_{3}\right)\right)$, $63.53\left(\mathrm{C}_{6}{ }^{\mathrm{C}(\mathrm{F})}\right), 69.61\left(\mathrm{C}_{5}{ }^{\mathrm{C}(\mathrm{F})}\right), 70.65,70.75,71.33,71.78\left(5 \mathrm{C}, 5 \times \mathrm{C}_{6}\right), 70.86,71.17$, 71.26, $71.40\left(5 \mathrm{C}, 5 \times \mathrm{C}_{5}\right), 71.67\left(\mathrm{C}_{3}{ }^{\mathrm{B}}\right), 74.35\left(\mathrm{C}_{2}{ }^{\mathrm{A}}\right), 78.43,78.99,79.86,80.77,80.93$, $81.02,82.08,82.17,82.23,82.31,82.52,82.64,82.68,82.82,82.89\left(16 \mathrm{C}, 5 \times \mathrm{C}_{2}, 5 \times \mathrm{C}_{3}\right.$, $\left.6 \times \mathrm{C}_{4}\right), 98.42\left(\mathrm{C}_{1}{ }^{\mathrm{A}}\right), 99.68,99.82,99.89,100.41,100.48\left(5 \mathrm{C}, 5 \times \mathrm{C}_{1}\right), 170.37,170.42$ $\left(2 \mathrm{C}, 2 \times \mathrm{CH}_{3} \underline{\mathrm{CO}}\left(\mathrm{C}_{2}{ }^{\mathrm{A}}, \mathrm{C}_{3}{ }^{\mathrm{B}}\right)\right), 170.54\left(\mathrm{CH}_{3} \underline{\mathrm{CO}}\left(\mathrm{C}_{6}{ }^{\mathrm{C}}(\mathrm{F})\right)\right)$; ESI-HRMS (m/z) Calcd for $\mathrm{C}_{57} \mathrm{H}_{100} \mathrm{NO}_{33}\left[\mathrm{M}+\mathrm{NH}_{4}\right]^{+}:$1326.6172. Found 1326.6201. Calcd for $\mathrm{C}_{57} \mathrm{H}_{96} \mathrm{O}_{33} \mathrm{Na}$ $[\mathrm{M}+\mathrm{Na}]^{+}:$1331.5726. Found 1331.5738. Calcd for $\mathrm{C}_{57} \mathrm{H}_{96} \mathrm{KO}_{33}[\mathrm{M}+\mathrm{K}]^{+}: 1347.5471$ Found 1347.5517.

\section{Acknowledgements}

Financial support of this study from CNRS and Sorbonne University, as well as the National Natural Science Foundation of China (grant nos. 81530090 and 21877007) are gratefully acknowledged. S. Xiao thanks the China Scholarship Council for a Ph.D fellowship. We would like to thank Dr. Xiaomeng Shi from State Key Laboratory of Natural and Biomimetic Drugs, Peking University for the tandem mass spectrometry experiments. 


\section{Supplementary data}

Supplementary data (copies of ${ }^{1} \mathrm{H}$ NMR, ${ }^{13} \mathrm{C}$ NMR, HRMS spectra for compounds 6-9 and MS/MS spectra of compound 6) associated with this article can be found, in the online version, at

\section{References}

1. Dodziuk, H. Cyclodextrins and their complexes: Chemistry, analytical methods, applications. Wiley, Weinheim. 2006.

2. Mathiron, D.; Marcon, F.; Dubaele, J. M.; Cailleu, D.; Pilard, S.; Djedaini-Pilard, F. Benefits of methylated cyclodextrins in the development of midazolam pharmaceutical formulations. J Pharm Sci-Us 2013, 102, 2102-2111.

3. Loftsson, T.; Vogensen, S. B.; Brewster, M. E.; Konradsdottir, F. Effects of cyclodextrins on drug delivery through biological membranes. J Pharm Sci-Us 2007, 96, 2532-2546.

4. Braga, S. S.; Gago, S.; Seixas, J. D.; Valente, A. A.; Pillinger, M.; Santos, T. M.; Goncalves, I. S.; Romao, C. C. $\beta$-cyclodextrin and permethylated beta-cyclodextrin inclusion compounds of a cyclopentadienyl molybdenum tricarbonyl complex and their use as cyclooctene epoxidation catalyst precursors. Inorg Chim Acta 2006, 359, 4757-4764.

5. Casu, B.; Reggiani, M.; Sanderson, G. R. Methylated cycloamyloses (cyclodextrins) and their inclusion properties. Carbohydr. Res. 1979, 76, 56-59.

6. Szejtli, J. Dimethyl- $\beta$-cyclodextrin as parenteral drug carrier. Journal of Inclusion Phenomena 1983, 135-150.

7. Krumkacheva, O. A.; Fedin, M. V.; Polovyanenko, D. N.; Jicsinszky, L.; Marque, S. R. A.; Bagryanskaya, E. G. Structural Equilibrium in New Nitroxide-Capped Cyclodextrins: CW and Pulse EPR Study. J Phys Chem B 2013, 117, 8223-8231.

8. Chen, Z.; Bradshaw, J. S.; Lee, M. L. A convenient synthesis of mono-6-hydroxy permethylated beta-cyclodextrin via tert-butyldimethylsilylation. Tetrahedron Lett 1996, 37, 68316834.

9. Cousin, H.; Cardinael, P.; Oulyadi, H.; Pannecoucke, X.; Combret, J. C. Synthesis of the three isomeric mono-2-, 3-, or 6-hydroxy permethylated beta-cyclodextrins and unambiguous high field NMR characterisation. Tetrahedron-Asymmetr 2001, 12, 81-88.

10. Suzuki, M.; Nozoe, Y. Facile preparation of mono-2-O-modified eicosa-Omethylcyclomaltoheptaoses (-beta-cyclodextrins). Carbohyd Res 2002, 337, 2393-2397.

11. Tisse, S.; Peulon-Agasse, V.; Oulyadi, H.; Marsais, F.; Combret, J. C. Selective access and full characterization of mono-acidic permethylated beta-cyclodextrin derivatives and their methyl esters. Tetrahedron-Asymmetr 2003, 14, 2259-2266.

12. Kordopati, G. G.; Tsivgoulis, G. M. Amino cyclodextrin per-O-methylation: Synthesis of 3monoamino-permethylated derivatives. Tetrahedron Lett 2018, 59, 2447-2449.

13. du Roizel, B.; Baltaze, J. P.; Sinay, P. Diisobutylaluminum-promoted secondary rim selective de-O-methylation of permethylated cyclodextrins. Tetrahedron Lett 2002, 43, 2371-2373.

14. Mao, Q. Y.; Kitagishi, H. Optimized synthesis of a per-O-methylated-cyclodextrin dimer linked at the secondary face by a pyridine ligand. J Incl Phenom Macro 2019, 93, 67-76.

15. Pearce, A. J.; Sinay, P. Diisobutylaluminum-promoted regioselective de-O-benzylation of perbenzylated cyclodextrins: A powerful new strategy for the preparation of selectively modified 
cyclodextrins. Angew Chem Int Edit 2000, 39, 3610-3612.

16. Luo, X. Y.; Chen, Y.; Huber, J. G.; Zhang, Y. M.; Sinay, P. Diisobutylaluminum hydride as a molecular scalpel: the regioselective stripping of four methyl groups from permethylated betacyclodextrin. Cr Chim 2004, 7, 25-28.

17. Chen, Y.; Huber, J. G.; Zhang, Y. M.; Sinay, P. Regioselective one-step synthesis of hexahydroxy permethylated beta-cyclodextrin and unambiguous NMR analysis. $\mathrm{Cr}$ Chim 2005, 8 , 27-30.

18. Xiao, S.; Yang, M.; Sinaÿ, P.; Blériot, Y.; Sollogoub, M.; Zhang, Y. Diisobutylaluminium Hydride (DIBAL-H) Promoted Secondary Rim Regioselective Demethylations of Permethylated $\beta$ Cyclodextrin: A Mechanistic Proposal. European Journal of Organic Chemistry 2010, 2010, 15101516.

19. Xiao, S.; Zhou, D.; Yang, M.; Sinaÿ, P.; Sollogoub, M.; Zhang, Y. Facile preparation of two tetrols from permethylated $\alpha$-cyclodextrin and unambiguous NMR analysis. Tetrahedron Lett 2011, 52, 5273-5276.

20. Xiao, S.; Yang, M.; Yu, F.; Zhang, L.; Zhou, D.; Sinaÿ, P.; Zhang, Y. Synthesis of four monofunctionalized $\alpha$-cyclodextrin derivatives for further confirming DIBAL-H-promoted bis-de-Omethylation mechanism. Tetrahedron 2013, 69, 4053-4060. 